\title{
Explaining the Behavior of Fluctuations in the Returns of Jordanian Banks: An Analytical Study
}

\author{
Submitted 11/05/20, $1^{\text {st }}$ revision 22/06/20, $2^{\text {nd }}$ revision 30/07/20, accepted 31/08/20 \\ Khaled Abdalla AL-Tamimi ${ }^{1}$, Samer Fakhri Obeidat ${ }^{2}$, Emad Saud Hajjat ${ }^{3}$
}

\begin{abstract}
:
Purpose: The study attempted to identify the most important factors that affect the investment returns of Jordanian banks 'shares in the financial market.

Design/Approach/Methodology: By using statistical models and lag time variables (one year lag) to interpret the return on investment per share in the current year, it is concluded that there was no statistically significant effect of the following independent factors: capital adequacy, surpluses, cash, market value-added, liquidity ratio, and trading volume on return on investment for commercial bank shares.

Findings: The study showed a statistically significant effect of the size of the assets and the tax rate on the return on investment of commercial banks' shares. Moreover, the independent factors explain 55\% of the fluctuations that occur in the profitability of banks.

Practical Implication: The study recommends paying attention to intellectual capital (added market value). It was not statistically significant and important as a factor that reflects the extent of banking awareness among clients and the extent of their acceptance of banks' new banking services.

Originality/value: This study is original and attempted to identify the most important factors that affect the investment returns of Jordanian banks 'shares in the financial market.
\end{abstract}

Keywords: Banks returns, investment returns, capital adequacy, surplus cash, market value added, liquidity ratio.

JEL code: $G 14$.

Paper type: Research article.

\footnotetext{
${ }^{l}$ Department of Administrative and Financial Sciences, Irbid University College, Al-Balqa' Applied University, Jordan. e-mail: khaled_tamimi@yahoo.com;

${ }^{2}$ Department of Administrative and Financial Sciences, Irbid University College, Al-Balqa' Applied University, Jordan. e-mail: samerfo_82@yahoo.com;

${ }^{3}$ Department of Administrative and Financial Sciences, Irbid University College, Al-Balqa'

Applied University, Jordan. e-mail: Hajiatemad@Gmail.com;
} 


\section{Introduction}

The main pillar of the continuation and growth of any bank in light of the rapid developments is the creation of administrative and financial factors that affect the growth of investment returns. The primary goal is to maintain their survival and enhance their financial position, through the ability to achieve cash surpluses represented by the difference between the incoming cash inflows and outcoming cash flows. Some banks found that modern administration do not depend on returns on investment in the material sense only, but also on ideas or what is known as intellectual capital that creates loyalty among clients and investors in dealing with the bank. Here, it measures the bank's management efficiency in generating the owners' revolution and increasing profits from its total investments while maintaining reducing risks to lowest levels.

\section{Objectives of the Study}

It seeks to explain fluctuations in return on investment for shares of Jordanian banks listed on the Amman Stock Exchange. To achieve this, the study tries to answer the following questions:

$>$ Is the Amman Stock Exchange a fertile environment for achieving investment returns?

$>$ How is this fertile environment measured - if any?

$>$ Can the financial indicators that are the subject of the study explain the behavior of investment returns in stocks?

The importance of these questions come first, if the return on investment for the shares of banks on the Amman Stock Exchange is not determined randomly, then the bank's current financial indicators can be used to forecast future investment returns and second when we try to explain the behavior of investment returns for stocks, it facilitates knowing the climate and dealers of the financial market, and it has to set investment policies to achieve returns.

\section{Research Hypotheses}

There is no statistically significant effect of the study variables in explaining the behavior of fluctuations in bank profitability. The study population is represented by 15 Jordanian banks whose shares are listed on the Amman Stock Exchange during the study period from 2003-2018, some of which were excluded due to insufficient data during the study period, so 11 commercial banks were approved, knowing that numbers were extracted study variables through the financial statements published on the Amman Stock Exchange. The study relied on the descriptive-analytical approach, and since we use the variables of the past year to explain the return on investment per share in the current year (Lagged model) the number of observations per variable is eliminated by one. The proposed model is as follows: 
Epst $=($ MVAt-1) $($ A t-1) $(\mathrm{CA} \mathrm{t}-1)(\mathrm{L} \mathrm{t}-1)(\mathrm{CS} \mathrm{t}-1)(\mathrm{T} \mathrm{t}-1)(\mathrm{VT} \mathrm{t}-1)$

where:

The return on investment per share in the current year, is the dependent variable of the study (EPs t). It can be calculated by dividing the net annual income by the number of ordinary shares issued, and this measure shows the performance of the company and the extent of its ability to invest its assets effectively, and the rise in this measure is a good indicator of the success and efficiency of management in investment projects and policies.

MVA t-1 is the market value added in the last year. This variable also expressed by the intellectual capital represented by the difference between the value of stock prices in the financial market and the book value in the company records, this measure shows the knowledge base and awareness in assessing the efficiency of management through the optimal use of resources and promoting the shareholders' rights. The market value of the stock price is measured by the product of the market price multiplied by the number of ordinary shares issued. The book value is expressed in the total shareholders' equity in the company's records (Jadoua, 2016).

The size of the company in the last year (A) includes the total money in the bank, knowing that most of this money is for others and the capital is often not more than $10 \%$ of its assets, and the total assets were approved to measure the size of the company. Moreover, the total assets produced and utilized by the administration in a proper manner would increase the returns on investment (Tamimi and Obeidat, 2012).

Capital Adequacy in the past year (CA t-1) means being cautious and aware of the various risks that banks are exposed to from their operations. It is measured by dividing the total shareholders' equity by the total risky assets (Tamimi and Obeidat, 2013).

Dangerous assets are defined as all assets except liquid assets (cash, balances with the central bank, balances with banks and financial institutions). Examples of risky assets are loans with or without collateral and other securities (long-term investments) (Khraiwish et al., 2004).

(L t-1) is also known as the circulation ratio, which shows the extent of the bank's ability to meet its short-term liabilities coverage through cubes and the size of its current assets. The index of this ratio varies according to the nature of the bank's policy, and this indicator was calculated as follows (Siyam and Khraiwish, 2002):

Cash on hand + balance at the Central Bank + balances with banks in the Kingdom at the main center or branches operating outside the kingdom + bills + bills due within three months 
Deposits + other bank deposits + head office balances or branches operating outside the Kingdom + the uncovered part of the letters of guarantee (guarantees)

Cash surpluses (CS t-1) express the availability of investable cash. To exploit these surpluses, it is assumed that investment strategies that generate financial returns are adopted instead of remaining unexploited liquidity, calculated through the equation:

Cash surplus = cash and cash equivalents at the end of the year / Total right of owners

The increase in taxes ( $\mathrm{T} \mathrm{t}-1)$ leads to greater erosion of the banks' profits, thereby reducing the returns on investment for stocks. The study predicts that the tax relationship with the return on investment will be negative.

Trading Volume (VT t-1) is the extent to which investors want to buy the bank's shares, and the increase in this variable is evidence of the extent of investors rushing towards shares that achieve capital gains.

\section{Literature Review}

Abu Lebda (2019) presented the existence of a negative and moral effect with statistically significant effect for both the cost of deposits and the debt ratio on the targeted profits, and the study also found that the changes in the targeted profits are due to both the size of the bank, the cost of deposits and the leverage. This study by Siyam and Khraiwish (2002) sought to explain the factors affecting the profitability of commercial banks in Jordan and showed a direct relationship (significant) for property rights, debt ratio, cash surpluses, cash liquidity and advertising expenses.

Other studies headed a different direction from the above by listing three groups of independent variables that include the variables for banks, financial structure variables, and Jordanian macroeconomic variables using a pooled data regression technique. Results indicated that operating expense ratios are the most influential variables in bank profitability (overhead), followed by the relative size variable (RSIZE), then the concentration ratio (cr3), and then economic growth (GRTH) (Mashharawi and AL-Zubi, 2009). Another study by Tapia et al. (2010) indicates that the profitability of banks is higher and more sustainable when creditors receive good protection.

Moreover, when public or private credit bureaus are available, the return of owners increases, but the increase in information sharing will enhance competition between banks and weaken profitability in the future (Al-Jarrah et al., 2010). On highlighting external and internal determinants of bank profitability for the period 2000-2006 through the use of stable time series and stable chain models in various arrangements, the study revealed that the most important internal factor affecting profitability are the ratio of loans to total assets, the ratio of operating expenses, and 
the capital structure. As for the external factors, they were money supply and inflation. A study by Merhej et al. (2014) showed that the profitability of Syrian commercial banks is classified into two internal and external categories according to their importance as follows: profits or losses of securities, profits or losses of loans, monetary policy, deposits, liquidity and interest rates, social culture and banking awareness, counting branches, and competition. The difficult economic conditions in Syria have led to a deterioration in the profitability of banks. The study by Dawood (2014) also provided a comprehensive explanation to assess the profitability of commercial banks operating in Pakistan, where 23 banks were selected for the period from 2009 to 2012 showing the effects of internal factors (return on equity, effective cost, liquidity, capital adequacy, deposits, size of the bank). The study reached the following results: cost-effectiveness, liquidity, and capital adequacy are the factors that affect the profitability of commercial banks operating in Pakistan. The study also found that deposits and the size of the bank do not affect profitability.

Ejoh and Iwara (2014) tried to reveal the extent of capital adequacy on the profitability of deposit funds in five Nigerian banks in the period 1981-2011. The study revealed that capital adequacy plays an important role in interpreting the return on assets, which is a measure of the profitability of banks, and that the relationship is positive and statistically significant. There are also studies in which there is a kind of twisting that focused on one independent variable and using a standard model to know the extent of the impact of the capital adequacy index to several dependent variables expressed in the rate of shareholders' equity, earnings per share and return on assets for the period from 2008-2014, and indicated that the exaggeration in the increase in the capital adequacy index resulted in a decrease in all profitability indicators (Dubic, 2015). Also, the study by Jadoua (2016) has focused on the intellectual capital represented by the added market value and its reflection on the returns of investments in Iraqi banks. The study showed in its final image that there is a positive moral effect of the added market value in enhancing and increasing the profitability of banks.

\section{Study Results}

Table 1 shows a summary of the descriptive statistics of the independent variables and the dependent variable of the commercial banks, where the average, median, highest value, lowest value, median, and the standard deviation for each of the variables appear. The return rates on investment for the average and median were $(0.5599)$ and $(0.22)$ respectively reflecting that the Jordanian banks are achieving good profit rates. Moreover, for the added market value the average and the median were (3.26E + 08), $(4.52 \mathrm{E}+07)$. However, we note that the size of the bank was on average $(3.10 \mathrm{E}+09)$ and its median $(1.17 \mathrm{E}+09)$. As Table 1 shows the average capital adequacy (0.17234) and its median (0.177) indicate that commercial banks maintain $17 \%$ of the weighted assets with risks, this is a good percentage compared to the rate imposed by the Central Bank of Jordan, which is (12\%). Table 1 also 
shows that the average liquidity ratio and its median are (0.448909) and (0.45), respectively.

Table 1. Shows descriptive statistics for independent variables and dependent variable

\begin{tabular}{lccccccc|cr|}
\hline & EPS & \multicolumn{1}{c}{ MVA } & \multicolumn{1}{c}{ A } & CA & L & CS & \multicolumn{1}{c}{ T } & VT \\
\hline Mean & 0.559 & $3.26 \mathrm{E}+08$ & $3.10 \mathrm{E}+09$ & 0.17234 & 0.44890 & 2.2213 & 13093333 & $1.25 \mathrm{E}+08$ \\
\hline Median & 0.22 & $4.52 \mathrm{E}+07$ & $1.17 \mathrm{E}+09$ & 0.177 & 0.45 & 1.64 & $5.42 \mathrm{E}+06$ & $1.72 \mathrm{E}+07$ \\
\hline Max & 15.82 & $9.28 \mathrm{E}+09$ & $2.59 \mathrm{E}+10$ & 0.31604 & 0.89 & 12.86271 & $1.29 \mathrm{E}+08$ & $3.35 \mathrm{E}+09$ \\
\hline Min & -0.36 & $-9.80 \mathrm{E}+07$ & $6.68 \mathrm{E}+06$ & -0.39648 & 0.17 & -3.04944 & -2075411 & $1.17 \mathrm{E}+05$ \\
\hline Std. D. & 2.053 & $1.08 \mathrm{E}+09$ & $5.66 \mathrm{E}+09$ & 0.07527 & 0.13237 & 2.12507 & 21215449 & $3.78 \mathrm{E}+08$ \\
\hline
\end{tabular}

Source: Own study.

The correlation matrix is used to show the relationship between independent and dependent variables on the one hand and between the independent variables among them, on the other, to ensure that there is no strong correlation between them, which indicates what is known as the double correlation between the two variables and the multiple between more than two variables which negatively affects the sincerity of the regression results. Table 2 indicates that the relationship between independent variables, between return on investment and assets is weak (0.3540). Moreover, between them and the added market value is less than $60 \%$, and it is also weak in the sense that there are no double or multiple correlations between the model's independent variables.

Table 2. The correlation matrix appears between the independent and dependent variables

\begin{tabular}{|l|l|l|l|l|l|l|l|l|}
\multicolumn{1}{l|}{} & EPS & MVA & A & CA & L & CS & T & VT \\
\hline EPS & 1 & & & & & & & \\
\hline MVA & 0.105399 & 1 & & & & & & \\
\hline A & 0.354061 & 0.6089142 & 1 & & & & & \\
\hline CA & -0.11761 & 0.1089549 & 0.12985 & 1 & & & & \\
\hline L & 0.046575 & 0.0431800 & -0.0352 & 0.14920 & 1 & & & \\
\hline CS & 0.081879 & -0.083510 & -0.1101 & -0.1781 & 0.58739 & 1 & & \\
\hline T & 0.149955 & 0.5734743 & 0.93048 & 0.18576 & -0.1056 & -0.184 & 1 & \\
\hline VT & 0.059701 & 0.2900692 & 0.5622 & 0.1314 & 0.03287 & -0.0931 & 0.5326 & 1 \\
\hline
\end{tabular}

Source: Own study.

\subsection{Regression Results}

The fixed-effects model, the random-effects model, and the Haussmann test were estimated. The Hausman test results indicated that the fixed effects model is appropriate for the factors affecting the returns on investment in commercial banks operating in Jordan, where the probability of significance level was less than $5 \%$. The results of the regression analysis are presented in Table 3. It shows that the minimum capital adequacy, cash surpluses, and the market value-added effect are negative on the return rate on investment. However, it is not statistically significant, their value reached $(-2,210,1091),(0.050970))$, and $(-2.25 \mathrm{E}-10)$, respectively. 
Table 3. The effect of factors affecting returns on investment in commercial banks in Jordan appears

\begin{tabular}{|l|c|c|}
\hline \multicolumn{1}{|c|}{ Independent Variables } & \multicolumn{2}{|c|}{ Dependent Variables } \\
& $\begin{array}{c}\text { EPS } \\
\text { Fixed effects model }\end{array}$ & $\begin{array}{c}\text { EPS } \\
\text { Random effects model }\end{array}$ \\
\hline \multirow{2}{*}{ A-1 } & $7.59 \mathrm{E}-10$ & $6.58 \mathrm{E}-10$ \\
& $(11.79354)^{* * *}$ & $(11.22165)^{* * *}$ \\
\hline \multirow{2}{*}{ CA-1 } & -2.291091 & -1.951332 \\
& $(-1.361940)$ & $-1.203549)$ \\
\hline \multirow{2}{*}{ CS-1 } & -0.050970 & $(-0.346440$ \\
& $(-0.677692)$ & 0.058925 \\
\multirow{2}{*}{ L-1 } & 0.57113 & $(0.053677)$ \\
\hline \multirow{2}{*}{ MVA-1 } & $(0.507166)$ & $-2.61 \mathrm{E}-10$ \\
& $-2.25 \mathrm{E}-10$ & $(-2.051274)^{* *}$ \\
\hline \multirow{2}{*}{ T-1 } & $(-0.699039)$ & $-1.33 \mathrm{E}-07$ \\
& $-1.43 \mathrm{E}-07$ & $(-8.786839)^{* * *}$ \\
\hline \multirow{2}{*}{ VT-1 } & $(-8.877032)^{* * *}$ & $-6.11 \mathrm{E}-10$ \\
& $1.94 \mathrm{E}-10$ & $(-0.783316)$ \\
\hline Adjusted R-squared & $(0.214332)$ & 0.410512 \\
\hline F-statistic & 0.550250 & 17.31533 \\
\hline Hausman test Chi-Sq & 12.80276 & 165 \\
\hline Prob (Chi-Sq) & 36.383102 & 11 \\
\hline NO & 0000 & 165 \\
\hline Banks & 11 & \\
\hline
\end{tabular}

Source: Own study.

Table 3 indicates that the effect of both the liquidity rate and the trading volume is positive on the rates of return on investment. However, they are not statistically significant, as their value reached (0.571113) and (10-94E), respectively. Moreover, the results of the fixed effects model always indicate positive and statistically significant impact on the rate of return on investment for commercial banks operating in Jordan, and this indicates that banks in Jordan improve the optimization of operating and exploiting their assets in a manner that increases their profits. Moreover, the tax is always negative and statistically significant in its impact on the rate of return on investment for commercial banks, where it reached (-1.43E-07), and this result is logical because the taxes are expended and their rise is a burden that leads to high deductions and the resultant erosion of profits. Adjusted R-squared states that $55 \%$ of the independent factors explain the changes in return rates on investment in the commercial banks operating in Jordan.

\section{Conclusion and Recommendations}

The results of the analysis show that the relationship of the independent factors, capital adequacy, cash surpluses, added market value, liquidity ratio, and trading volume correspond to the assumptions of the study, whereas the result related to the size of the assets and the tax rate does not correspond to the assumptions of the study. The independent factors explain 55\% of the changes in the return rates on 
investment in the commercial banks operating in Jordan. The study recommends paying attention to intellectual capital (added market value) although it was not statistically significant and important as a factor that reflects the extent of banking awareness among clients and the extent of their acceptance of new banking services.

\section{References:}

Abu Lebda, S. 2019. Determinants of Profitability in Jordanian Commercial Banks Using the Partial Modification Form: A Study on Jordanian Commercial Banks Listed on the Amman Stock Exchange (2007-2016). University of Al-Bayt Jordan.

Al-Jarrah, I., Ziadat, K., El-Rimaw, S. 2010. The Determinants of the Jordanian's Banks Profitability: A Cointegration Approach. Jordan Journal of Business Administration, 6(2), 247-261.

AL-Tamimi, K., Obeidat, S. 2013. Determinants of Capital Adequacy in Commercial Banks of Jordan an Empirical Study. International Journal of Academic Research in Economics and Management Sciences, 2(4), 44-58.

Al-Tamimi, K., Obeidat, S. 2012. The determinants of the profitability of Jordanian commercial banks, an applied study. Irbid Journal of Research and Studies, 16(1), 292-317.

Dawood, U. 2014. Factors impacting profitability of commercial banks in Pakistan for the period of (2009-2012). International Journal of Scientific and Research Publications, 4(3), 1-7.

Debek, H. 2015. The Relationship between the Application of the Capital Adequacy Standard in Accordance with Basel Decisions and the Profitability of Local Commercial Banks in Palestine. (Master Thesis) Islamic University, Gaza, Palestine.

Ejoh, N., Iwara, U. 2014. The Impact of Capital Adequacy on Deposit Money Banks' Profitability in Nigeria. Research Journal of Finance and Accounting, 5(12), 7-15.

Jadoua, M. 2016. Intellectual capital and its reflection on investment returns. Applied research on a sample of banks listed in the Iraq Stock Exchange. Journal of Economic and Administrative Sciences, 22(92), 344-359.

Khraiwesh, H, Al-Zoubi, K, Al-Abadi, M. 2004. Factors Affecting the Degree of Banking Security: A Field Study. King Abdulaziz University, Journal of Economics and Administration, 18(2), 59-77.

Mashharawi, F., Al-Zu'bi, K. 2009. The Determinants of Bank's Profitability: Evidence from the Jordanian Banking Sector (1992-2006). Jordan Journal of Business and Administration, 5(3), 403-414.

Merhej, M, Hammouda, A.W, Mazeeq, R. 2014. Determining the Factors Affecting the Profitability of Commercial Banks Using Multivariate Analysis: A Field Study in the Syrian Commercial Bank in Lattakia Governorate. Tishreen University Journal for Research and Scientific Studies - Economic and Legal Sciences Series, 36(2), 325-345.

Siyam, W, Khuryush, H. 2002. Factors Affecting the Profitability of Commercial Banks in Jordan, King Abdulaziz University Arab Journal of Economics and Administration, 16(2), 133-150.

Tapia, B., Tascon, M., Fanjul, J. 2010. Country Creditor Rights, Information Sharing, and Commercial Banks' Profitability. Czech Journal of Economics and Finance, 60(4),336-354. 